\title{
PHILIP FRENEAU'S FATHER
}

\author{
By Lewis Leary
}

Professor Leary, of the University of Miami, Florida, again gives us a glimpse into bis findings in the Rutgers Library as be completes bis work on a new biograpby of Pbilip Freneau. A year ago be allowed us to print for the first time since their original appearance in the New Brunswick Fredonian a number of poems by Freneau. This time be is revealing the significance of a book of transcripts of letters which were kept by Pierre Fresneau, the fatber of Pbilip. Former biographers bave presented Pbilip Freneau as born into the tradition of wealth and culture. Here for the first time be is shown to bave come from far more bumble origins.

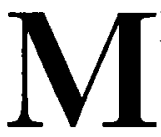

ISFORTUNE seems to have followed each of the Fresneaus in America. André, who came to New York in 1709 from France by way of London, did enjoy, it is true, a short period of prosperity. When he died in 1725 , however, his estate was bound in litigation. His widow and his three sons were forced to sell one after another of his holdings until what small fortune the doughty merchant had amassed was dissipated. Of his sons, the oldest, Andrew, is last heard of in debtor's prison. Francis, the youngest, died intestate on the island of Surinam, a fugitive from his creditors. ${ }^{1}$ Although the details of their downfalls are shrouded in the darkness which the past mercifully casts upon failure, Pierre Fresneau, André's second son and the father of Philip Freneau, the Poet of the American Revolution, has left a more complete record of his own unsuccessful attempts to launch a commercial career. This record, a letter book containing transcripts of Pierre Fresneau's correspondence from 1744 until his death in 1767 , is in the Rutgers University Library.

"I take the oppt . . . to inform you," Pierre Fresneau wrote from Madeira early in I744, "of my being enter'd in to partnership with two Portuguze Gentlemen that by their Skill in Wine, if my friends in America remember me, will Certainly make my Fortune." Thus at twenty-seven he announced the formation of "P. Fresneau \& Company" which proposed to export wines "whose Quality we hope will Quite Establish our house." Pierre

\footnotetext{
1 A more complete story of André, Andrew, and Francis Fresneau will be told in the writer's forthcoming critical biography of Philip Freneau.
} 
Fresneau had already had some experience in trade. Two years before he had been "beyond the seas in North Carolina," apparently an agent or supercargo for his older brother. Later he had been briefly employed in some commercial capacity by David Clarkson, a merchant of Philadelphia. Whether his recent suffering through an unsuccessful love affair of which he complained, "I have been treated the most ungreatfully of all men," had anything to do with his decision to become a factor in Madeira, we do not know. At any rate, he now set up his own business. "We propose ourselves to be," he said, "the best Shippers in the Island.",

On August I, 1743, shortly after his arrival at Madeira, he had sent one batch of letters to America. Now, on February 20 of the next year, a schooner lay moored in the harbor about to sail for New York. Pierre Fresneau wrote feverishly. "The multiplicity of my letters," he apologized, "obliges me to be brief." His correspondents included some of the first names of colonial America. Among others, he wrote to Abraham Van Courtlandt, Samuel Livingston, Isaac Beauchamp, Brandt Schuyler, Cornelius Van Horne, Abram D. Peyster, Gilian Van Planck, Nicholas Bayard, David Provoost, and Anthony Rutgers. From each he solicited custom as the only British-American trader, "one from Maryland excepted," on the island. He asked for consideration, however, not "merely for the sake of Country butt because he was Capable of Shiping Wines No way Inferiour." To former associates of André Fresneau he submitted his qualifications, his aspirations: "If one whose Father was So well Known can have any affect upon Ye American Gentlemen $\&$ his Intention to Return again among Them and make his Country the better for his own Success he Flatters himself Every Gentleman will give him the Preferance to all heare Establishd for who riches $\mathrm{N}$ th America is never Like to be the better.",3

Soon shipments of beeswax, codfish, nails, cheese, beans, Indian corn, and other produce were sent from New York to P. Fresneau and Company. ${ }^{4}$ In return, pipes of wine were dispatched from Madeira, including " an excellent parcel of wines of the Jesuits wch every body allows to be the best in the is-

2 February 20, 1744 .

3 Ibid.

4 See February 26 and March 8, 1744. 
land." Pierre Fresneau particularly cultivated the New York trade; thus, he said "we shall have the Less occasion to Ship extraordinary wines elsewhere, wch is not the Case with any of the Factors here, who from an ambitious view of enlarging their correspondnece solicit business in Engl. Holland, Ireland, the West Indies." In such a situation, he advised his American clients, "your country comes Badly off."' "Our wines," he confided with optimism, "begin to show themselves \& will in all appearances Turn out Extraordinary this Year."6

It took weeks, however, for letters to reach America and as long again for orders to be returned to the island. Foodstuffs did not stand up well on the long sea voyage. Pierre Fresneau complained to his brother of a cargo the latter had sent: the fish were poor, the cheeses rotten, the beans greatly short of the quantity called for. He suspected the sailors of pilfering, "a practice," he said, "often made use of especially by Berdians." " Nor did the wines fare better. "My Brother Andrew Fresneau informs me," Pierre wrote to a customer in New York, "of his having sold you a pipe of wine that prov'd sour wch has given me much Concern But which I hope will never happen for the future." He humbly invited further "tryal of P. Fresneau \& Company." "I hope," he concluded, "we will serve you in such a manner as will Leave you no Room to com-

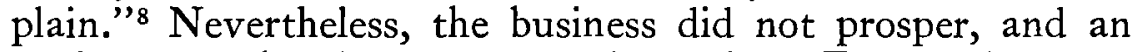
anxious note breaks recurrently in to Pierre Fresneau's correspondence. "Nothing," he asserted, "gives me so much concern as to find several of my best friends (as I thought) give their business to Strangers sooner then to their Country man after knowing me to be Capable of Remitting them as good wine . . . as any other house can for their lives!'9

Yet, though orders lapsed, the young merchant did not forget his friends in America. To William Bradford, the Philadelphia printer who had kept him supplied with newspapers, he sent a present of a large barrel of lemons. ${ }^{10}$ Francis Fresneau's bride received a goldfinch which sang charmingly. To his relatives among the Huguenot colony in New York he dispatched

- April 30, I745.

- February 20, 1744 .

${ }^{7}$ May 5,1745 .

8 May I 5,1745 .

- February 20, 1744 .

${ }^{10}$ February 10, 1747 . 
a special basket of figs." In return, Pierre solicited "something gay" which he might present to the sixteen year old daughter of one of his partners. For himself, he needed three glass lanthorns, a spy glass, and a pen knife. ${ }^{12}$ Most of all, however, he wrote despairingly to his brother, he needed trade: "All our fine expectations are come to nothing." 13

$\mathrm{He}$ encountered difficulties among the islanders of Madeira as well as with his customers in New York. "There is no doing business for a quart of wine without letter upon letter to all our Country Gentry with whom we deal which is the cause of our losing very much." ${ }^{14}$ Even when a cargo was ready for shipping, there was often no vessel available for its transport. "Your Disappointing us in sending us ye Brig you so long talkd of," Pierre Fresneau wrote to his older brother, "has been a Prodigious loss to us in ye wines we had prepared for her which we know not how your unfortunate brother can sustain." 15 When Andrew, however, suggested that they become partners in a brig of their own, Pierre replied haughtily, "Your brother does not care to be concernd in shipping . . . therefore returns you his thanks."16 So, for periods of months at a time the young merchant waited a vessel to carry his wines to America.

In the meantime he appealed to his younger brother: "We are strongly prepossessed with the notion . . . that was you to take a journey as far as Boston you might create... friends throughought New England and thereby get us large consignments from them." 17 When nothing came of this suggestion, Pierre took the matter in his own hands, announced to his brothers and to William Bradford late in 1747 that he himself would take the first available ship home. ${ }^{18}$ This he did and, after a passage of fifty-two days which was chiefly remarkable for ugly weather, landed at New York early in January of 1748 . "By the beginning of March, I propose, God Willing," he wrote to his partners, "to start for New England, where it will be necessary for me to stay until midsummer." His itinerary

\footnotetext{
11 January 12, 1747.

12 February i 8, 1747 .

${ }_{13}$ August 28, 1747.

${ }^{14}$ February I 8, 1747.

${ }^{15}$ October 7, I 747.

${ }_{16}$ February 18, 1747.

17 February 18, 1747.

${ }_{18}$ November 19, 1747.
} 
would then take him to Philadelphia and the "western ports," and, finally, to the Carolinas. ${ }^{19}$ The en terprise was handicapped, however, by the severity of the weather, the condition of the roads, and an illness which, he was careful to explain to his associates in Madeira, "My Doctor attributes to my great exercise ... on horseback in order to procure business for our house." 20

Time passed, one delay after another was encountered, and the correspondence between Pierre Fresneau and his partners became perfunctory and short tempered. To make matters worse, Andrew Fresneau, having advertised that he intended to settle his affairs and leave New York forever, ${ }^{21}$ had disappeared. Francis had fled the country deeply in debt. "He has proved," Pierre wrote angrily, "an arent rogue, the shame of his country and family." It only aggravated the situation that this youngest of the Fresneaus soon turned up in Madeira where, Pierre complained, "he had the impudence to Settle himself in my house." To his partners there he wrote, "Tis ye advice of all my friends that you turn him immediately out . . . of my house and make him pay rent for the time he lived in it." ${ }^{22}$ Both Andrew and Francis Fresneau owed P. Fresneau \& Company large sums of money for wines they had taken on consignment. The partners despaired of ever collecting any of it. Pierre Fresneau hid his embarassment behind a screen of well articulated anger. ${ }^{23}$

At some time during the course of his travels over the American colonies, Pierre Fresneau met Agnes Watson, twenty-three year old daughter of a prosperous Scotch yeoman from Monmouth county, New Jersey. Her father, David, her uncles, and her brothers, all had extensive holdings in farmlands. They were a steady and industrious people, active members of the Old Scots church at Freehold..$^{24}$ It was not long before Pierre Fresneau, archly defending himself against his partners' accusations that he was neglecting business for personal affairs, ${ }^{25}$ posted a marriage bond with the governor of the province of East New-Jersey. Then, on March I2, I750, he took Agnes

${ }^{19}$ January 24, 1748. $\quad{ }^{20}$ October 18, I748. $\quad{ }^{21}$ New York Gazette, May 4, 1748.

${ }^{22}$ September I4, 1748 . ${ }^{23}$ June $21,1748$.

${ }^{24}$ See John E. Stillwell, Historical and Genealogical Miscellany: Early Settlers of New Fersey and T'beir Descendants (New York, I932), pp. 250-54; F. R. Symmes, History of tbe Old Tennent Cburcb (Cranbury, 1904), p. 367; and the Fresneau Family Bible.

${ }^{25}$ February $13,175^{\circ}$. 
Watson as his bride. ${ }^{26}$ His was an excellent good choice. The placid common sense and Scotch tenacity which his wife brought to their union was to pay high dividends. More immediately important, however, the established family connections which she placed at Pierre Fresneau's disposal undoubtedly warded off the failure which had overcome each of his brothers.

Two years later, after his first son, Philip, had been born in New York and after he had built a house upon property which belonged to the Watsons at Mount Pleasant in Monmouth county, Pierre Fresneau sailed once more for Madeira. Upon his return early in $\mathrm{I} 753$, he wrote to his former associates: "Finding my crossing of the seas attended with no manner of success . . ., I have given over the wine trade and have established me in the Jerseys where I am now with my family."'27 He entered partnership with Peter Watson, his wife's cousin. "My friends," Pierre Fresneau explained, "have built me a house near a convenient landing where I carry on a dry goods trade and make returns of country produce to New York." Thus, he submitted, "I hope after a few years to better my circumstances." 28

But Pierre Fresneau seems never to have been quite happy in the quiet of the Monmouth countryside. Submission to such rural retirement was not, moreover, apparently expected of him: "Perhaps," he suggested, "it will surprise my friends.", ${ }^{9}$ As time went on, then, he became restless. "It is now near a twelve month since I was in New York," he complained. "30 "I have almost forgot my Portugeze." 31 He hoped "a little time longer will ... bring some of the Farmers with whom I am daily making acquaintance to venture their produce to Sea." 32 To his friends in Madeira he affirmed: "I am become quite a farmer but despair not (if God assists me) to be concerned once more with my favorite isle." 33 Soon, however, he dolefully admitted, "My family is again on the increase. . . . I don't know if I shall ever have time to make another trip." 34

Four more children were born to Pierre and Agnes Fresneau. Trade in Monmouth county moved slowly. But, though cash was always a "very scarce Article," the family at Mount

\footnotetext{
${ }^{26}$ Licenses of Marriages, Office of the Secretary of State of New Jersey, F, 29.

${ }^{27}$ March 13, 1753. $\quad{ }_{28}^{28}$ July 9, I754. $\quad{ }_{29}^{29}$ March 12, I753. ${ }_{80}^{80}$ October 5, 1753.

${ }^{31}$ July 9, I754. $\quad{ }^{32}$ October 5, 1753. $\quad{ }^{33}$ May 12, $1756 . \quad{ }^{34}$ July 9, 1756.
} 
Pleasant seem never to have been seriously in want. In $I 762$ Pierre Fresneau received deed to almost four hundred acres of land, including a sawmill, from his brother-in-law, David Watson. ${ }^{35} \mathrm{By}$ this time his affairs seem to have become more prosperous. His activities extended to New York, where he was known respectfully as Peter Fresneau, Gent. ${ }^{36}$ There he petitioned the Common Council for rights to waterfront property along the harbor ${ }^{37} \mathrm{He}$ invested in lands in upper New York state. ${ }^{38}$ His mill at Monmouth turned out lumber and cordwood for the urban market. His fields produced garden truck and grain, enough "blessd bt God," he said, "to carry us the Year Round." 39

But failure finally closed in upon Pierre Fresneau as it had closed in upon his father and each of his brothers. Creditors became "very urgent for their money." "If they once begin to fall upon me," he said, "it must certainly terminate in my ruin." He tried to raise funds among his Huguenot friends in New York. He complained to his cousin, John Morin Scott, that the latter's failure to lend him one hundred pounds "must inevitably have fatal consequences." $40 \mathrm{He}$ attempted to mortgage the lands which he had purchased in upper New York state. ${ }^{41}$ Failing in this, he advertised his holdings for sale. ${ }^{42} \mathrm{He}$ sent load after load of timber from his sawmill in an attempt to stave off disaster. ${ }^{43}$ Nothing succeeded.

When Pierre Fresneau died on October I7, I767, he left his family a debt of thirteen hundred pounds for which the homestead at Mount Pleasant was later offered at public auction.4 "Here ends," Philip Freneau wrote on the last page of his father's letter book, "a Book of Vexations, disappointments, Loss and Plagues, that sunk the Author to his grave short of 50 years."

${ }^{35}$ Monmouth County Deeds, K, 60.

${ }^{36}$ Collections of the New York Historical Society (1897) XXX, 417-18.

${ }^{37}$ Minutes of the Common Council (New York, 1905), VII, $3^{2}$ and $3^{8 .}$

${ }^{38}$ Arcbives of the State of New Fersey, 1st ser., XXXIII, 153-58.

${ }^{39}$ July I, I767.

$10 \mathrm{July}, 1767$.

11. August 29, 1767 .

- See New York fournal, September 3, 1767 .

${ }^{43}$ August 27,1767 .

4 See Wills, Office of the Secretary of State of New Jersey, K, 6I, and Monmouth County Deeds, R, 449 . 